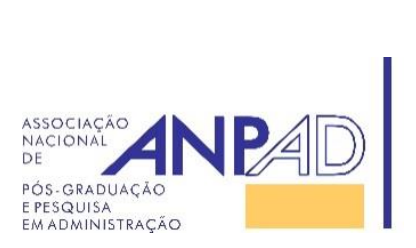
Disponível em
http://www.anpad.org.br/rac
RAC, Rio de Janeiro, v. 22, n. 1, art. 5,
pp. 92-114, janeiro/fevereiro, 2018,
http://dx.doi.org/10.1590/1982-7849rac2018170004

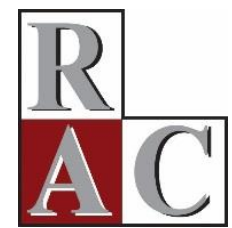

\title{
Capital Structure Adjustment in Brazilian Family Firms
}

Eduardo K. Kayo ${ }^{1}$ Eduardo Ottoboni Brunaldi ${ }^{1}$

Dante M. Aldrighi ${ }^{1}$

Universidade de São Paulo ${ }^{1}$

Artigo recebido em 06.01.2017. Última versão recebida em 18.07.2017. Aprovado em 23.07.2017. 


\title{
Resumo
}

Analisamos em que medida as companhias familiares são diferentes das companhias não familiares em termos de endividamento e ajuste da estrutura de capital. Aplicando um modelo de trade-off dinâmico a uma amostra de companhias brasileiras de 2003 a 2013, foi mostrado que companhias familiares apresentam maior nível de endividamento e menor velocidade de ajuste em comparação às companhias não familiares. Argumenta-se que companhias familiares tendem a ter maior endividamento porque seus gestores são mais confiantes e otimistas que gestores de empresas não familiares. Restrições financeiras derivadas desse alto nível de endividamento previnem empresas familiares sobre alavancadas de ajustar-se rapidamente para uma estrutura de capital alvo.

Palavras-chave: estrutura de capital; firmas familiares; velocidade de ajuste; maior acionista último.

\begin{abstract}
We examine the extent to which family companies are different from non-family companies in their leverage ratios and their capital structure adjustment. By applying a dynamic trade-off model to a sample of Brazilian companies for 2003-2013, we show that family companies have higher leverage and slower adjustment speeds in comparison to non-family companies. We argue that family companies' managers tend toward higher leverage because they are more confident and optimistic than managers of non-family firms. Financial constraints stemming from this high leverage prevent over-leveraged family firms from rapidly adjusting their target capital structure.
\end{abstract}

Key words: capital structure; family firms; speed of adjustment; largest ultimate shareholder. 


\section{Introduction}

Family companies have been in the center of intense academic investigation and scrutiny during recent years. In particular, scholars have investigated the differing performance between family and nonfamily companies (e.g., Anderson \& Reeb, 2003a; Miller, Le Breton-Miller, Lester, \& Cannella, 2007; Wagner, Block, Miller, Schwens, \& Xi, 2015). Many studies suggest significant heterogeneity between these types of firms, which leads to differences in performance, investment rates (e.g., Kuo \& Hung, 2012; Schmid, Ampenberger, Kaserer, \& Achleitner, 2015), and financing policy (e.g., Crespí \& MartínOliver, 2015; López-Gracia \& Sánchez-Andújar, 2007). Despite this vast literature, there is no consensus about whether family companies outperform non-family companies. Likewise, the issue of the differences in investment and financing decisions between family and non-family companies is far from settled.

Understanding which firm traits are important to drive investment and financing decisions has important impacts for theory and practice. The speed of adjustment of leverage, in particular, is a subject of intense debate about the validity and applicability of diverse theoretical perspectives. While the speed of adjustment perspective assumes that firms rebalance their capital structure to pursue a target leverage (e.g., Flannery \& Rangan, 2006; Hovakimian, Opler, \& Titman, 2001), other perspectives disregard the existence of such a target (e.g., Baker \& Wurgler, 2002; Myers \& Majluf, 1984; Welch, 2004). For practitioners, in turn, the understanding of what makes a given firm have a fast or slow adjustment of capital structure is important for helping them to choose the appropriate source of funding and to understand the impacts of their choice on a firm's investments and performance.

This study focuses on family and non-family companies' financing decisions and the extent to which financial constraints affect both types of firms' financing decisions. More specifically, we analyze the discrepancies between family and non-family companies with regards to their leverage and their speed of adjustment to a target. While López-Gracia and Sánchez-Andújar (2007) find that family companies adjust to the target faster than non-family firms do, our results show a slower speed of adjustment. We argue that stronger financial constraints on family firms in Brazil are responsible for this result, creating higher costs to adjust the capital structure and thereby reducing their ability to promptly return to optimal leverage levels. Besides the speed of capital structure adjustment, we also analyze the level of leverage in family and non-family companies, which is still a controversial subject (e.g., Anderson, Mansi, \& Reeb, 2003; Anderson \& Reeb, 2003b; Gallo, Tàpies, \& Cappuyns, 2004; Hackbarth, 2008; McConaughy, Matthews, \& Fialko, 2001).

This paper's main contribution is its novel empirical evidence on the relationship between firms' family ownership and capital structure adjustment. Previous studies investigated the influence of family ownership on firms' financing decisions (Agrawal \& Nagarajan, 1990; Crespí \& Martín-Oliver, 2015; Gallo et al., 2004; McConaughy et al., 2001) and on capital structure adjustment (e.g., López-Gracia \& Sánchez-Andújar, 2007). However, we extend these studies by showing contrasting results in the Brazilian environment, particularly with regards to the capital structure speed of adjustment of family firms. To the best of our knowledge, the only study that examines the effect of family ownership on capital structure adjustments is an article by López-Gracia and Sánchez-Andújar (2007).

However, we differ from this in two important ways. First, we find contrary results. While LópezGracia and Sánchez-Andújar (2007) find that family firms are faster to adjust their capital structure, we find that Brazilian family firms are slower. In the next section, we provide theoretical arguments for this difference. Second, and more importantly, we take into account the pyramidal ownership structure of the firms, by using the concept of last ultimate shareholder (LUS) to build our definition of family firms. We believe that identifying the LUS allows us clarify who actually owns and controls firms and is a better criterion for classifying a firms' owners.

The remainder of this paper is organized as follows: In the next section we review the literature and develop the hypotheses. In the sequence we describe the data and the variables and introduce the dynamic trade-off model. At last, we discuss the empirical results and conclude. 


\section{Theoretical Framework and Hypotheses Development}

Capital structure is still a very controversial subject in the finance field. At least since the Modigliani and Miller's (1958) irrelevance proposition, several theories compete to explain firms' financing decisions. These theories, often, are difficult to reconcile. The traditional trade-off theory (Kraus \& Litzenberger, 1973), for instance, advocates that the balancing between benefits (e.g., tax benefits) and costs (e.g. financial distress) of debt defines an optimal level of leverage. From this point of view, firms would pursue a target leverage that maximizes their value. Incidentally, a survey by Graham and Harvey (2001) shows that $81 \%$ of the firms in their sample pursue some level of target leverage, with $37 \%$ of the firms indicating that they have "flexible targets", $34 \%$ having "somewhat tight target/range", and 10\% having a "very strict target" (p. 218).

These results suggest that while most firms do not have a specific target leverage, but they at least have a target range to which they may converge. In line with this target leverage argument, several studies suggest that capital structure is highly stable over time (e.g., Lemmon, Roberts, \& Zender, 2008), even though DeAngelo and Roll (2015) show evidence that this stability holds only for a small fraction of firms. Contrary to the trade-off hypothesis, however, other important theories such as pecking order (Myers \& Majluf, 1984), market timing (Baker \& Wurgler, 2002), and managerial inertia (Welch, 2004) offer alternative motivations for financing decisions and disregard the existence of optimal target leverage.

In our study, we assume that firms, in general, have at least a flexible target leverage, a possibility supported by Graham and Harvey's (2001) survey. A flexible target leverage implies that firms can eventually deviate from their target or even set a new one due to changes in internal or external environments. Incidentally, some studies (e.g., Uysal, 2011) show evidence that firms can deviate from their target leverages when they face relevant investment demands. For example, Uysal (2011) shows that over-leveraged firms rebalance their capital structure by decreasing their leverage when they expect to acquire another firm. Having said that, in the following subsections we provide theoretical arguments to support our main hypotheses regarding family firms' financing decisions.

\section{Family firms' leverage}

Do distinct factors motivate financing decisions in family firms? Using debt to finance investment may raise a firm's bankruptcy risk, harming shareholders and consequently increasing the risk that the controlling family will be forced to relinquish control of the company. Consistent with this perspective, Crespí and Martín-Oliver (2015), Gallo, Tàpies and Cappuyns (2004), McConaughy Matthews, and Fialko (2001), and Agrawal and Nagarajan (1990) present evidence that family companies have less leverage than non-family companies, even when low leverage impairs their growth.

In contrast, Anderson and Reeb (2003b) and Anderson, Mansi and Reeb (2003) show no significant difference in the level of debt between family companies and non-family companies when the decision maker is concerned with business continuity. These researchers argue that although both types of companies follow a pecking order model of financing, they do so for different reasons: family companies issue equity only as a last resort because controlling families fear losing control of the firm (Blanco-Mazagatos, Quevedo-Puente, \& Castrillo, 2007).

Finally, behavioral finance-based arguments may explain why family firms have higher levels of leverage. From this perspective, managers' decisions are frequently biased by excessive optimism and overconfidence. These two biases are fundamentally different from each other, but generate the same result: the false perception that the firm is undervalued. While optimistic managers systematically overestimate their firm's cash flow (Heaton, 2002), overconfident managers underestimate earnings riskiness (Hackbarth, 2008), that is, the discount rates applied to firm's cash flows. Because of the perception that their firms are undervalued, optimistic and overconfident managers believe that external sources of financing, particularly new equity, are overpriced or "unduly costly" (Malmendier, Tate, \& 
Yan, 2011, p. 1729), thereby making them to avoid equity issuances. If external finance is necessary, these managers will prefer to use debt first.

Although we do not directly test the effect of behavioral biases on firm leverage, optimism and overconfidence can possibly explain why the Brazilian firms in our sample are overleveraged. A previous study of Brazilian companies (Barros \& Silveira, 2008) shows that most are classified as "biased" (p. 318) by excessive optimism and overconfidence is controlled by families. Based on this evidence and since our sample is very similar to that of Barros and Silveira, we assume that behavioral biases that possibly dominate our sample of family firms can at least partially explain our results. In light of this previous research, we propose:

Hypothesis 1. Leverage is higher in family firms than non-family firms.

\section{Capital structure adjustments}

The growing literature on capital structure adjustment speed estimates that companies modify their leverage to the target on a range that varies from $25 \%$ to $40 \%$ per year (e.g., Faulkender, Flannery, Hankins, \& Smith, 2012; Flannery \& Hankins, 2013; Flannery \& Rangan, 2006; Huang \& Ritter, 2009). Investigations in Brazil show similar results. Bogéa, Sheng, and Lora (2012), for instance, find speeds of adjustment as high as $24 \%$ for Brazilian firms, while Barros and Silveira (2008) find a range from $20 \%$ to $35 \%$. While these studies help clarify the dynamics of firms' financing decisions, the range is quite large, suggesting that some omitted factors are responsible for this high variance. Recent studies helped fill this gap by identifying some factors that influence firms' capital structure adjustment speed, such as corporate governance features (Chang, Chou, \& Huang, 2014), high bankruptcy costs (Elsas \& Florysiak, 2011), evidence that companies with poor governance structures adjust faster when product market competition is more intense (Chang, Chen, Chou, \& Huang, 2015), and a positive relationship with cash flow realization (Faulkender et al., 2012).

Ownership structure is another possible source of the differences in firms' speed of adjustment. López-Gracia and Sánchez-Andújar (2007) show that leverage adjustment of small Spanish family firms is faster than of non-family companies, arguing that family companies' lower leverage facilitates the raising of new debt and a swift adjustment to the capital structure target. They claim that the leverage of family companies is lower because family activism substitutes for debt as a governance mechanism to constrain the agency costs of equity, making debt unnecessary as a disciplinary device to control discretionary behavior. As agency theory suggests, debt is an efficient governance arrangement when free cash flow is high (Jensen, 1986).

However, our results regarding the level of debt contradict those of López-Gracia and SánchezAndújar (2007). We show that Brazilian family companies have more debt than non-family companies. Therefore, the governance substitution effect does not apply in the Brazilian case, thereby invalidating the argument of a faster speed of adjustment stemming from a low debt level. Consequently, we have to set an alternative explanation for the speed of adjustment of Brazilian family firms' leverage.

When firms are over-leveraged, which is the case of family firms in Brazil, the capital structure is more likely to be adjusted through the issuance of new equity (Lyandres, 2010) instead of debt decreases. However, it is well known that the direct (i.e., gross spreads) and indirect costs (i.e., underpricing) of issuing equity are very high (e.g., Butler, Grullon, \& Weston, 2005; Corwin, 2003; Lee \& Masulis, 2009; Lyandres, 2010). These issuance (i.e., adjustment) costs make the capital structure balancing less frequent and, consequently, slower. In addition, raising external capital through debt would make family firms even more overleveraged. Overall, these facts suggest that family firms can be more financially constrained than non-family firms.

If family companies face more financial constraints, it likely costs them more to adjust their capital structure, and hence they take more time to do so. Korajczyk and Levy (2003) suggest that financially constrained companies make different decisions about capital structure compared to unconstrained firms. More specifically, financially unconstrained firms issue new equity when 
economic conditions are favorable (pro-cyclically, timing the market) and act counter-cyclically in issuing new debt. Thus, unconstrained firms can afford to deviate from their target leverage more often and revert faster and more easily.

In contrast, financially constrained firms cannot adjust their capital structure as fast as financially unconstrained firms can because it is more difficult for them to borrow, especially after adverse economic shocks (Korajczyk \& Levy, 2003). They also have limited scope for issuing new equity. For this reason, constrained family firms tend to show a slower adjustment speed. Thus, we propose the following:

Hypothesis 2. Family firms have a slower capital structure adjustment speed than non-family companies.

\section{Methods}

\section{The dynamic trade-off model}

Based on previous studies (e.g., Flannery \& Rangan, 2006), we employ a partial adjustment model to estimate companies' annual speed of adjustment to a target level of leverage, which, in turn, is a function of several lagged firm variables, represented by the vector $\mathbf{X}$ and its respective parameter $\theta$ in equation (1):

$$
\operatorname{LEV}_{\mathrm{i}, \mathrm{t}}^{*}=\theta \mathbf{X}_{\mathrm{i}, \mathrm{t}-1}
$$

Flannery and Rangan (2006) argue that companies fail to adjust promptly to a target debt level due to high adjustment costs. Equation 2 represents the standard partial adjustment model that estimates firms' annual speed of adjustment to the target leverage:

$$
\mathrm{LEV}_{\mathrm{i}, \mathrm{t}}-\mathrm{LEV}_{\mathrm{i}, \mathrm{t}-1}=\omega\left(\mathrm{LEV}_{\mathrm{i}, \mathrm{t}}^{*}-\mathrm{LEV}_{\mathrm{i}, \mathrm{t}-1}\right)+\varepsilon_{\mathrm{i}, \mathrm{t}-1}
$$

Substituting [1] into [2], we have:

$$
\mathrm{LEV}_{\mathrm{i}, \mathrm{t}}=\gamma \mathrm{X}_{\mathrm{i}, \mathrm{t}-1}+(1-\omega) \mathrm{LEV}_{\mathrm{i}, \mathrm{t}-1}+\varepsilon_{\mathrm{i}, \mathrm{t}-1}
$$

Substituting $(1-\omega)$ for $\beta_{1}$ :

$$
\mathrm{LEV}_{\mathrm{i}, \mathrm{t}}=\gamma \mathrm{X}_{\mathrm{i}, \mathrm{t}-1}+\beta_{1} \mathrm{LEV}_{\mathrm{i}, \mathrm{t}-1}+\varepsilon_{\mathrm{i}, \mathrm{t}-1},
$$

where $\gamma$ is the parameter of the vector of variables that determines the target leverage and $\left(1-\beta_{1}\right)$ is the estimated speed of adjustment to the target leverage. By definition, $\beta_{1}$ varies from 0 to 1 .

To analyze the specific effect of family ownership on speed, we include an interaction variable between the binary variable fam, which takes a value of 1 for family firms and 0 otherwise, as well as lagged leverage. The parameter of this interaction is $\beta_{2}$, which indicates the partial effect of family ownership.

$$
\mathrm{LEV}_{\mathrm{i}, \mathrm{t}}=\beta_{0}+\beta_{1} \mathrm{LEV}_{\mathrm{i}, \mathrm{t}-1}+\beta_{2} \mathrm{LEV}_{\mathrm{i}, \mathrm{t}-1} \cdot \mathrm{fam}_{\mathrm{i}, \mathrm{t}-1}+\gamma \mathrm{X}_{\mathrm{i}, \mathrm{t}-1}+\varepsilon_{\mathrm{i}, \mathrm{t}-1} \varepsilon_{\mathrm{i}, \mathrm{t}-1},
$$

To account for unobserved heterogeneity and to address potential autocorrelation in the residuals, we use dynamic panel GMM estimators: Arellano and Bond's (1991) difference GMM and Blundell and Bond's (1998) system GMM. 


\section{Data}

We use data from publicly traded Brazilian companies for the period 2003-2013. We manually collected ownership and control data from mandatory reports that these firms are required to file with Securities and Exchange Commission of Brazil (Comissão de Valores Mobiliários [CVM]). We source the financial data from Economatica. In line with previous studies, we exclude firms belonging to banking and public utilities industries (e.g., Chang et al., 2014; Fama \& French, 2002; Flannery \& Rangan, 2006; Uysal, 2011) from the sample. The reason why banking companies, as financial intermediaries, are excluded from our sample relies on Fama and French (1992), who say that "the high leverage that is normal for these firms probably does not have the same meaning as for nonfinancial firms, where high leverage more likely indicates distress" (p. 429).

Public utilities, in turn, are excluded because their financial decisions depend on the regulatory environment within they work. For example, the Brazilian Electricity Regulatory Agency is the government agency responsible for supervising and authorizing companies to explore electricity generation, distribution, and transmission. Energy exploration licenses have defined terms (e.g., 30 years) that can be extended or not, thereby affecting firms' investments and financing decisions, especially when the terms are about to expire. To decrease the effect of outliers, we winsorize all variables at the upper and lower one-percentiles. Our final sample consists of 1,937 firms-year observations for 257 firms from 19 industries.

\section{Measures}

\section{Leverage}

There is controversy about the best measure for leverage. Those who use book leverage (BookLev), the ratio of total debt to total assets, argue that market variables are unreliable because of the vagaries of stock markets. According to Graham and Harvey (2001), there is no evidence suggesting that managers adjust companies' capital structure based on equity market valuations. Incidentally, Myers (1977) claims that growth opportunities - that is, firms' market values - are not appropriate drivers for financing decisions and that managers closely monitor book leverage as a result of the fact that tangible assets in place can be used as collaterals. In contrast, researchers who use market leverage note that this measure provides a better description of the relative contribution of creditors and shareholders to the firms' capital (Welch, 2004). We follow some recent studies (e.g., Chang et al., 2014; Flannery \& Rangan, 2006) and use market leverage (MktLev), which is the ratio of total debt to the sum of the total debt and the company's market value.

\section{Family firms}

Despite the historical importance of family firms globally, there is no standard definition (Miller et al., 2007; Miralles-Marcelo, Miralles-Quirós, \& Lisboa, 2014). Fahlenbrach (2009), for instance, defines family companies as those in which the founder or co-founder plays the role of Chief Executive Officer regardless his/her shareholding; Barth, Gulbrandsen, and Schønea (2005), however, suggest that one person or a family should hold $33 \%$ of the shares, at minimum, for the firm to be a family company.

In our paper, family companies are those whose largest ultimate shareholder (LUS) - the shareholder owning the largest direct or indirect stake in the company's voting rights - is a family or individual. An indirect ownership structure - also known as pyramidal - means that the ultimate shareholder has an equity stake in the sample company through at least one intermediate company. To identify each firm's LUS, we investigated its largest direct shareholders. If these shareholders are other companies, we verify these firm's direct shareholders to determine the sample companies' indirect shareholders; if shareholders in this second ownership layer are also companies, we identify their direct shareholders, and so on, until we reached the ultimate shareholder in the ownership chain. Thereafter, we represent the ownership structure for each sample company annually from 2003 to 2013 in an 
organogram, pinpointing the main shareholders' voting rights for each intermediate firm throughout the ownership chain. The LUS may be a family, the government, a pension fund, non-residents, or investment companies. We use a 50\% cutoff to distinguish firms with a controlling shareholder from widely held firms.

The calculation of a shareholder's voting rights when there is indirect ownership depends on whether at least one voting capital stake along the ownership chain is below $50 \%$. In that case, we reckon the voting rights by multiplying the voting capital stakes along each of the ownership chains and adding the corresponding products. By contrast, if the ultimate shareholder holds voting capital stakes along the ownership chain that are above the 50\% cutoff, then the shareholder's voting capital stake is provided by the direct voting capital stake that the intermediate firm in the first layer holds in the sample firm.

We believe that identifying the LUS allows us clarify who actually owns and controls firms and is a better criterion for classifying a firms' owners. To the best of our knowledge, no previous study uses the LUS concept to analyze the capital structure of family companies. This is particularly important in Brazil, where business groups that achieve control by means of complex ownership structures involving dual-class shares and pyramidal schemes prevail. During the 2003-2013 period, families were the LUS in approximately $65 \%$ of the publicly traded firms in Brazil and held $61 \%$ of the voting rights on average.

Using the LUS concept, we use two criteria to define family companies. First, family companies are those whose LUS is a family. Second, we consider not only the LUS' particular category but also whether it has control of the firm: a family firm is therefore one that is controlled by an LUS who is a family. Based on this criterion, the binary variable for family firms takes the value of 1 if the LUS is a family holding at least $50 \%$ of the voting rights, and 0 otherwise.

\section{Control variables}

We follow Flannery and Rangan (2006) and Flannery and Hankins (2013) to select the firms' characteristics (the $\mathbf{X}$ vector). Profitability (EBIT_TA) is the ratio of earnings before interest and taxes to total assets. According to trade-off theory, profitable companies tend to be more leveraged because the availability of cash flows implies lower bankruptcy risks and tax shields yield more benefits. We proxy firm size by the natural logarithm of total assets (LnTA). Larger firms tend to be more leveraged because they are supposed to be more transparent and have better access to capital markets (Chang $e t$ al., 2015). Tangibility (FA_TA) is the ratio of fixed assets to total assets. Arguably, companies owning more tangible assets can use them as debt collateral and obtain easier access to credit.

We use market-to-book ratio (MTB) as a proxy for growth opportunities and define it as the ratio of a firm's market value to total assets. We expect that firms with a high MTB will avoid debt because of the high costs of bankruptcy. The depreciation rate (DEP_TA) is the ratio of depreciation to total assets. We expect that the higher the depreciation allowance, the lower the benefit from debt tax shields, thereby making these companies have less leverage. To control for non-observable sector-specific characteristics, we use the mean leverage for the sector to which the firm belongs (IND_LEV). Finally, the variable AGE is the age of the companies.

\section{Empirical Results}

\section{Summary statistics and preliminary results}

Table 1 indicates that, regardless of the criterion used, Brazilian family firms tend to be older, smaller, and less profitable; they invest less, have fewer growth opportunities, have fewer tangible assets, have a lower depreciation index, and are more leveraged than non-family companies. The differences in their market leverage, in particular, are significant at the $1 \%$ level. Family companies' higher leverage is also reflected in their book leverage (but only by criterion 1 and at the $10 \%$ level), 
which is measured as the ratio of total debt to total assets. We can also see that family firms predominate in our sample if we use criterion 1 (that allows a firm to be familiar even if the family has small shareholdings). Not surprisingly, the number of family firms decrease when we use criterion 2, which demands that a family has the control of the firm.

Table 1

\section{Summary Statistics}

\begin{tabular}{|c|c|c|c|c|c|c|c|c|c|c|}
\hline \multirow[t]{3}{*}{ Variables } & \multicolumn{5}{|c|}{ Criterion 1} & \multicolumn{5}{|c|}{ Criterion 2} \\
\hline & \multicolumn{2}{|c|}{ Family firms } & \multicolumn{2}{|c|}{ Non-family firms } & \multirow[t]{2}{*}{ Difference } & \multicolumn{2}{|c|}{ Family firms } & \multicolumn{2}{|c|}{ Non-family firms } & \multirow[t]{2}{*}{ Difference } \\
\hline & $\mathrm{N}$ & Mean & $\mathrm{N}$ & Mean & & $\mathrm{N}$ & Mean & $\mathrm{N}$ & Mean & \\
\hline MktLev & 1254 & 0.326 & 683 & 0.254 & $0.072 * * *$ & 878 & 0.342 & 1059 & 0.266 & $0.076 * * *$ \\
\hline IND_LEV & 1255 & 0.311 & 683 & 0.281 & $0.030 * * *$ & 879 & 0.317 & 1059 & 0.287 & $0.030 * * *$ \\
\hline BookLev & 1254 & 0.254 & 683 & 0.238 & $0.015^{*}$ & 878 & 0.255 & 1059 & 0.243 & 0.012 \\
\hline EBIT_TA & 1255 & 0.068 & 683 & 0.095 & $-0.026 * * *$ & 879 & 0.065 & 1059 & 0.088 & $-0.023 * * *$ \\
\hline LnTA & 1255 & 20.765 & 683 & 21.277 & $-0.511 * * *$ & 879 & 20.584 & 1059 & 21.245 & $-0.660 * * *$ \\
\hline MTB & 1255 & 0.811 & 683 & 1.132 & $-0.321 * * *$ & 879 & 0.714 & 1059 & 1.099 & $-0.384 * * *$ \\
\hline DEP_TA & 1200 & 0.028 & 668 & 0.035 & $-0.006 * * *$ & 833 & 0.029 & 1035 & 0.033 & $-0.003^{* * *}$ \\
\hline FA_TA & 1255 & 0.269 & 683 & 0.294 & $-0.025^{* *}$ & 879 & 0.287 & 1059 & 0.270 & $0.017 *$ \\
\hline AGE & 1252 & 42.354 & 678 & 37.513 & $4.841 * * *$ & 876 & 45.157 & 1054 & 36.910 & $8.248^{* * *}$ \\
\hline
\end{tabular}

Note. This table presents the summary statistics of family and non-family firms according to the two criteria presented in the section on measures. The sample is composed of all publicly traded companies in Bovespa (Brazil's stock exchange) in the 2003-2013 period, excluding firms from banking and public utilities industries. MktLev is the ratio of total debt to total debt plus market equity value. IND_LEV is the industry leverage ratio. BookLev is the ratio of total debt to total assets. EBIT_TA is the ratio of EBIT over total assets. LnTA is the natural logarithm of total assets. MTB is the ratio of the company's market value to the book value of the assets. DEP_TA is the ratio of depreciation allowances to total assets. FA_TA is the ratio of fixed assets to total assets. AGE is the age of the companies We winsorize all variables at the upper and lower one-percentiles. Criterion 1 distinguishes family firms from non-family firms by focusing on whether the LUS is a family regardless its shareholding, whereas criterion 2 on whether the LUS is a family who controls the company. Data are taken from Economatica, firms' financial statements, and CVM reports.

The column Difference reports the $t$-test for the difference of variables means and $* * *, * *$ and $*$ represent statistical significance levels at one percent, five percent, and ten percent.

Table 2 shows the descriptive statistics of market and book leverages by industry (following Economatica classification), according to our criterion 1. To save space, we do not report the results using criterion 2, but they are similar. Except for banking and utilities, which are excluded from our analyses, one can see that our sample comprises firms from a wide range of industries. In addition, the distribution of family and non-family firms across these different industries seems to be proportional. Thus, it is unlikely that our main results stem from industry bias. 
Table 2

Descriptive Statistics of Market and Book Leverages by Industry (Criterion 1)

\begin{tabular}{|c|c|c|c|c|c|c|c|c|c|c|c|c|}
\hline \multirow[t]{3}{*}{ Industry } & \multicolumn{6}{|c|}{ Family firms } & \multicolumn{6}{|c|}{ Non-family firms } \\
\hline & \multirow[t]{2}{*}{$\mathrm{N}$} & \multirow[t]{2}{*}{$\%$} & \multicolumn{2}{|c|}{$\begin{array}{l}\text { Market } \\
\text { leverage }\end{array}$} & \multicolumn{2}{|c|}{$\begin{array}{l}\text { Book } \\
\text { leverage }\end{array}$} & \multirow[t]{2}{*}{$\mathrm{N}$} & \multirow[t]{2}{*}{$\%$} & \multicolumn{2}{|c|}{$\begin{array}{l}\text { Market } \\
\text { leverage }\end{array}$} & \multicolumn{2}{|c|}{$\begin{array}{l}\text { Book } \\
\text { leverage }\end{array}$} \\
\hline & & & Mean & S.D. & Mean & S.D. & & & Mean & S.D. & Mean & S.D. \\
\hline Agriculture & 22 & $1.8 \%$ & 0.334 & 0.192 & 0.294 & 0.117 & 11 & $1.6 \%$ & 0.157 & 0.163 & 0.148 & 0.153 \\
\hline Food and beverage & 95 & $7.6 \%$ & 0.430 & 0.251 & 0.320 & 0.178 & 43 & $6.3 \%$ & 0.345 & 0.215 & 0.331 & 0.169 \\
\hline Retail & 81 & $6.5 \%$ & 0.159 & 0.197 & 0.177 & 0.203 & 54 & $7.9 \%$ & 0.204 & 0.146 & 0.276 & 0.145 \\
\hline Building & 163 & $13.0 \%$ & 0.388 & 0.261 & 0.227 & 0.150 & 57 & $8.3 \%$ & 0.395 & 0.285 & 0.260 & 0.139 \\
\hline Electronics & 40 & $3.2 \%$ & 0.265 & 0.201 & 0.165 & 0.125 & 28 & $4.1 \%$ & 0.084 & 0.151 & 0.057 & 0.112 \\
\hline Non-Financial holdings & 68 & $5.4 \%$ & 0.309 & 0.314 & 0.212 & 0.213 & 32 & $4.7 \%$ & 0.236 & 0.247 & 0.216 & 0.176 \\
\hline Non-metallic minerals & 15 & $1.2 \%$ & 0.277 & 0.174 & 0.258 & 0.153 & 10 & $1.5 \%$ & 0.088 & 0.136 & 0.059 & 0.037 \\
\hline Mining & 10 & $0.8 \%$ & 0.209 & 0.132 & 0.200 & 0.105 & 18 & $2.6 \%$ & 0.206 & 0.132 & 0.263 & 0.086 \\
\hline Machinery & 31 & $2.5 \%$ & 0.296 & 0.204 & 0.270 & 0.157 & 11 & $1.6 \%$ & 0.415 & 0.296 & 0.382 & 0.228 \\
\hline Other light industries & 21 & $1.7 \%$ & 0.355 & 0.252 & 0.247 & 0.139 & 20 & $2.9 \%$ & 0.146 & 0.139 & 0.158 & 0.111 \\
\hline Others & 140 & $11.2 \%$ & 0.251 & 0.236 & 0.233 & 0.180 & 66 & $9.7 \%$ & 0.189 & 0.162 & 0.192 & 0.136 \\
\hline Other services & 40 & $3.2 \%$ & 0.183 & 0.239 & 0.173 & 0.191 & 26 & $3.8 \%$ & 0.208 & 0.234 & 0.215 & 0.169 \\
\hline Pulp and paper & 48 & $3.8 \%$ & 0.452 & 0.181 & 0.368 & 0.177 & 13 & $1.9 \%$ & 0.382 & 0.137 & 0.396 & 0.060 \\
\hline Chemistry & 78 & $6.2 \%$ & 0.388 & 0.209 & 0.321 & 0.158 & 67 & $9.8 \%$ & 0.181 & 0.194 & 0.170 & 0.161 \\
\hline Iron and steel & 136 & $10.8 \%$ & 0.376 & 0.247 & 0.278 & 0.161 & 75 & $11.0 \%$ & 0.231 & 0.181 & 0.198 & 0.162 \\
\hline Software and data & 18 & $1.4 \%$ & 0.064 & 0.083 & 0.126 & 0.147 & 8 & $1.2 \%$ & 0.018 & 0.021 & 0.060 & 0.087 \\
\hline Transportation & 45 & $3.6 \%$ & 0.304 & 0.197 & 0.355 & 0.171 & 51 & $7.5 \%$ & 0.277 & 0.182 & 0.355 & 0.162 \\
\hline Textile & 143 & $11.4 \%$ & 0.343 & 0.283 & 0.222 & 0.170 & 40 & $5.9 \%$ & 0.415 & 0.262 & 0.311 & 0.180 \\
\hline Automobile & 60 & $4.8 \%$ & 0.340 & 0.209 & 0.333 & 0.160 & 53 & $7.8 \%$ & 0.345 & 0.216 & 0.286 & 0.149 \\
\hline Total & 1,254 & $100 \%$ & 0.326 & 0.252 & 0.254 & 0.178 & 683 & $100 \%$ & 0.254 & 0.221 & 0.238 & 0.170 \\
\hline
\end{tabular}

Note. This table shows the descriptive statistics (mean and standard deviation) of market and book leverage by industry, according to Economatica classification. The sample is composed of all publicly traded companies in Bovespa (Brazil's stock exchange) in the 2003-2013 period, excluding firms from banking and public utilities industries. Market leverage (MktLev) is the ratio of total debt to total debt plus market equity value. Book leverage (BookLev) is the ratio of total debt to total assets. We winsorize all variables at the upper and lower one-percentiles. Criterion 1 distinguishes family firms from non-family firms by focusing on whether the LUS is a family regardless its shareholding, whereas criterion 2 on whether the LUS is a family who controls the company. Data are taken from Economatica, firms' financial statements, and CVM reports. $* * *, * *$ and $*$ represent statistical significance levels at one percent, five percent, and ten percent.

As a preliminary test, we analyze the extent to which family and non-family firms are far from their target leverage. First, we estimate the target leverage for each firm by regressing firms' leverage against several firm characteristics and then taking the fitted values as the target leverage. This is a common strategy applied by previous studies (e.g., Dudley, 2012; Fama \& French, 2002; Faulkender et al., 2012; Uysal, 2011) to estimate the unobservable target leverage. We particularly follow Dudley's (2012) procedure by running firm fixed-effect regressions in order to account for unobserved firm heterogeneity. In unreported analyses, we run several regressions and tests (e.g., Breusch-Pagan and Hausman tests), which indicated firm fixed-effects as the most appropriate estimator. We run two slightly different models with results in Table 3. 
Table 3

Target Market Leverage (MktLev) Estimation

\begin{tabular}{|c|c|c|}
\hline & & \\
\hline & Model 1 & Model 2 \\
\hline EBIT_TA $_{\mathrm{i},-1-1}$ & $-0.186 * * *$ & $-0.165 * *$ \\
\hline & $(0.063)$ & $(0.081)$ \\
\hline $\operatorname{LnTA}_{i, t-1}$ & $0.050 * * *$ & $0.051^{* *}$ \\
\hline & $(0.017)$ & $(0.020)$ \\
\hline $\mathrm{MTB}_{\mathrm{i},-1}$ & $-0.054 * * *$ & $-0.054 * * *$ \\
\hline & $(0.008)$ & $(0.009)$ \\
\hline $\mathrm{DEP}_{-} \mathrm{TA}_{\mathrm{i}, \mathrm{t}-1}$ & -0.279 & -0.032 \\
\hline & $(0.417)$ & $(0.395)$ \\
\hline FA_TA $A_{i, t-1}$ & $0.138 * *$ & $0.133 * *$ \\
\hline & $(0.054)$ & $(0.056)$ \\
\hline IND_LEV ${ }_{\mathrm{i}, \mathrm{t}-\mathrm{1}}$ & 0.137 & \\
\hline & $(0.078)$ & \\
\hline Fixed-effects & & \\
\hline Firms & Yes & Yes \\
\hline Years & Yes & No \\
\hline Industry-years & No & Yes \\
\hline $\mathrm{N}$ & 1553 & 1553 \\
\hline Adj. $R^{2}$ & 0.7852 & 0.7970 \\
\hline
\end{tabular}

Note. This table presents the results from the estimation of the target leverage. The sample is composed of all publicly traded companies in Bovespa (Brazil's stock exchange) in the 2003-2013 period, excluding firms from banking and public utilities industries. Variables are defined in Table 1 and the section on measures. We winsorize all variables at the upper and lower onepercentiles. Data are taken from Economatica, firms' financial statements, and CVM reports.

$* * *, * *$ and $*$ represent statistical significance levels at one percent, five percent, and ten percent. The errors are clustered at firm level.

In Table 3, Model 1, we run a fixed effect (firm and year) regression with traditional determinants of capital structure commonly found in tests of speed of adjustment of leverage (e.g., Flannery \& Rangan, 2006). Model 2, in turn, does not include the mean industry leverage as a regressor, but controls for firm fixed-effects and the interaction between industry and years. Regardless of the specification, the results are similar between the two models and the coefficients signs are consistent with previous studies. We avoid analyzing every single variable because our main interest relies only on the fitted values generated by these regressions. However, it is important to notice that the adjusted $R^{2}$ of both models are somewhat high, around 79\%, suggesting that these models can explain a large portion of the leverage variance.

Table 4 shows the results related to the relationship between actual and target leverage of family and non-family firms, demonstrating that family companies are significantly overleveraged, whereas non-family companies are significantly underleveraged. 
Table 4

$t$-test of the Difference Between Means of the Firm's Target and Actual Market Leverage

\begin{tabular}{|c|c|c|c|}
\hline & Actual (1) & Target (2) & $\begin{array}{c}\text { Difference } \\
\text { (1) - (2) }\end{array}$ \\
\hline \multicolumn{4}{|c|}{ Panel A. Target leverage as fitted values of Model 1} \\
\hline \multicolumn{4}{|l|}{ Criterion 1} \\
\hline Non-family firms & 0.259 & 0.301 & $-0.042 * * *$ \\
\hline Family firms & 0.328 & 0.304 & $0.023 * * *$ \\
\hline \multicolumn{4}{|l|}{ Criterion 2} \\
\hline Non-family firms & 0.272 & 0.305 & $-0.033 * * *$ \\
\hline Family firms & 0.343 & 0.301 & $0.041 * * *$ \\
\hline \multicolumn{4}{|c|}{ Panel B. Target leverage as fitted values of Model 2} \\
\hline \multicolumn{4}{|l|}{ Criterion 1} \\
\hline Non-family firms & 0.260 & 0.303 & $-0.043 * * *$ \\
\hline Family firms & 0.328 & 0.304 & $0.024 * *$ \\
\hline \multicolumn{4}{|l|}{ Criterion 2} \\
\hline Non-family firms & 0.272 & 0.326 & $-0.053 * * *$ \\
\hline Family firms & 0.343 & 0.275 & $0.067 * * *$ \\
\hline
\end{tabular}

Note. This table presents the $t$-test of the difference between means of the company's target and actual market leverage. The sample is composed of all publicly traded companies in Bovespa (Brazil's stock exchange) in the 2003-2013 period, excluding firms from banking and public utilities industries. We winsorize all variables at the upper and lower one-percentiles. Criterion 1 distinguishes family firms from non-family firms by focusing on whether the LUS is a family regardless its shareholding, whereas criterion 2 on whether the LUS is a family who controls the company. Data are taken from Economatica, firms' financial statements, and CVM reports.

$* * *, * *$ and $*$ represent statistical significance levels at one percent, five percent, and ten percent.

Tables 1 and 4 provide initial findings that support our first hypothesis that family companies may have higher levels of leverage. However, one may argue that both the univariate statistics and the target leverage estimation ignore potential self-selection problems inherent to these analyses. All control variables we use to estimate the target leverage, for instance, may be endogenous to some extent. One way to address this issue is to test the effect of family ownership structure on the company's leverage using treatment effect techniques. Thus we run the "bias-corrected matching estimator" introduced by Abadie and Imbens (2011, p. 1) and Abadie, Drukker, Herr, and Imbens (2004).

Our interest result is the average treatment effect for the treated (ATET): the variation in leverage for the treatment group (family firms) contrasted to similar control companies (non-family firms). We allow for one matched observation per treated company and impose exact matching for industry classification. We use the Economatica classification scheme, resulting in 19 different industries (see Table 2 for all industries included in the analysis). As we run matching analyses with replacement, we allow control firms to be used for more than once, thus making it possible that one control firm matches two or more treated observations. In addition, we match firms by size, tangibility, profitability, marketto-book ratio, and age. Table 5 provides the results of this estimation. 
Table 5

\section{The Effect of Family Ownership on Leverage: Matching Estimation of Average Treatment Effects on the Treated (ATET)}

Leverage

Criterion 1

Difference between family firms and non-family firms $\quad 0.026 * *$

$(0.0125)$

Criterion 2

Difference between family firms and non-family firms $\quad 0.0300 * * *$

$(0.0135)$

Note. This table presents the matching estimator according to Abadie, A., Drukker, D., Herr, J. L., \& Imbens, G. W. (2004). Implementing matching estimators for average treatment effects in Stata. The Stata Journal, 4(3), 290-311; and Abadie, A., \& Imbens, G. W. (2011). Bias-corrected matching estimators for average treatment effects. Journal of Business \& Economic Statistics, 29(1), 1-11. http://dx.doi.org/10.1198/jbes.2009.07333. We allow one matched observation per treated firms and impose exact matching for industry classification. Our matching variables are size, tangibility, profitability, market to book ratio, and age. The sample is composed of all publicly traded companies in Bovespa (Brazil's stock exchange), excluding firms from banking and public utilities industries. Data are taken from Economatica, firms' financial statements, and CVM reports. We winsorize all variables at the upper and lower one-percentiles. Criterion 1 distinguishes family firms from non-family firms by focusing on whether the LUS is a family, and criterion 2 on whether the LUS is a family who controls the firm. $* * *, * *$ and $*$ represent statistical significance levels at one percent, five percent and ten percent.

As we can see from Table 5, family ownership is responsible for an increase in firms' leverage, by 2.6 p.p. with the first criterion and by 3 p.p. using the second criterion. These results reinforce our first hypothesis and are quite different from most of previous studies. For example, Agrawal and Nagarajan (1990), McConaughy et al. (2001), Gallo et al. (2004), and Crespí and Martín-Oliver (2015) find that their sample of family companies have less leverage than non-family companies. The argument for family companies having lower debt levels is based on their aversion to financial distress and the resulting reluctance to borrow from banks (Gallo et al., 2004). It seems this rationale does not fit Brazilian family firms, since we find that their leverage is higher than for non-family firms. A possible explanation for the higher leverage of Brazilian family firms comes from behavioral economics. Barros and Silveira (2008) suggest that family firms tend to be biased by excessive optimism and overconfidence. These biases, in turn, can make the managers of family firms believe that their firms are undervalued and, consequently, that external finance are excessively costly. As a result, managers of family firms avoid issuing new equity and will prefer debt, if internal funds are insufficient to meet their investment needs.

\section{Capital structure adjustment speed}

Table 6 provides the results of the partial adjustment model of equation 5 . The parameters in columns I and II refer to firms whose LUS is a family, and the coefficients in columns III and IV refer to firms whose LUS is both a family and the controlling shareholder. The coefficients in the odd columns were estimated by applying the difference GMM introduced by Arellano and Bond (1991) - henceforth $\mathrm{AB}$ - while the coefficients in the even columns were estimated by applying the system-GMM introduced by Blundell and Bond (1998) - henceforth BB. The results are consistent with our second hypothesis that family companies adjust to their target leverage significantly slower than non-family companies do.

The parameters in column I suggest that non-family companies adjust their capital structure by $74.37 \%(1-0.2563)$ per year, whereas the value for family firms is $69.21 \%(1-0.2563-0.0516)$. Using the system GMM (BB) estimator, the difference is slightly greater: $48.52 \%(1-0.5148)$ for non-family firms and $40.25 \%(1-0.5148-0.0827)$ for family companies. All coefficients are significant at the $1 \%$ level. The difference in the $\mathrm{AB}$ and $\mathrm{BB}$ estimation results likely stem from the short sample period. 
According to Flannery and Hankins (2013), a short-panel bias may affect the consistency of the coefficients. After comparing certain estimators, they conclude that the BB estimator yields less biased coefficients. The Sargan test of overidentifying restrictions suggests that we cannot reject the hypothesis that the instruments are valid. Moreover, there is no second-order autocorrelation in the error terms, which validates the instruments used for both estimators (Baltagi, 2008).

Table 6

Speed of Adjustment to the Target Leverage

\begin{tabular}{|c|c|c|c|c|}
\hline & & & & \\
\hline & \multicolumn{2}{|l|}{ Criterion 1} & \multicolumn{2}{|l|}{ Criterion 2} \\
\hline & $\mathrm{I}(\mathrm{AB})$ & II (BB) & III (AB) & IV (BB) \\
\hline \multirow[t]{2}{*}{ MktLevi,t-1 $_{i}$} & $0.2563 * * *$ & $0.5148 * * *$ & $0.2281 * * *$ & $0.5579 * * *$ \\
\hline & $(0.00)$ & $(0.00)$ & $(0.00)$ & $(0.00)$ \\
\hline \multirow{2}{*}{ MktLev $_{\mathrm{i}, \mathrm{t}-1} * \mathrm{FAM}_{\mathrm{i}, \mathrm{t}-1}$} & $0.0516 * * *$ & $0.0827 * * *$ & $0.0387 * * *$ & $0.0358 * * *$ \\
\hline & $(0.00)$ & $(0.00)$ & $(0.00)$ & $(0.00)$ \\
\hline \multirow[t]{2}{*}{ EBIT_TA $A_{\mathrm{i}, \mathrm{t}-1}$} & $-0.0704 * * *$ & $-0.1951 * * *$ & $-0.0928 * * *$ & $-0.2100 * * *$ \\
\hline & $(0.01)$ & $(0.01)$ & $(0.00)$ & $(0.01)$ \\
\hline \multirow[t]{2}{*}{$\operatorname{LnTA}_{i, t-1}$} & $0.0345 * * *$ & $0.0202 * * *$ & $0.0507 * * *$ & $0.0201 * * *$ \\
\hline & $(0.00)$ & $(0.00)$ & $(0.00)$ & $(0.00)$ \\
\hline \multirow[t]{2}{*}{$\operatorname{MTB}_{\mathrm{i}, \mathrm{t}-1}$} & $-0.0205 * * *$ & $-0.0348 * * *$ & $-0.0187 * * *$ & $-0.0350 * * *$ \\
\hline & $(0.00)$ & $(0.00)$ & $(0.00)$ & $(0.00)$ \\
\hline \multirow[t]{2}{*}{$\mathrm{DEP}_{-} \mathrm{TA}_{\mathrm{i}, \mathrm{t}-1}$} & $-0.1330 * *$ & $-0.3385 * * *$ & -0.0436 & $-0.4141 * * *$ \\
\hline & $(0.06)$ & $(0.03)$ & $(0.05)$ & $(0.03)$ \\
\hline \multirow[t]{2}{*}{$\mathrm{FA}_{-} \mathrm{TA}_{\mathrm{i}, \mathrm{t}-1}$} & $0.0822 * * *$ & $0.1279 * * *$ & $0.0788 * * *$ & $0.1244 * * *$ \\
\hline & $(0.01)$ & $(0.00)$ & $(0.01)$ & $(0.01)$ \\
\hline \multirow[t]{2}{*}{ IND_LEV $_{\mathrm{i}, \mathrm{t}-1}$} & $-0.1235^{* * * *}$ & $-0.1461 * * *$ & $-0.1221 * * *$ & $-0.1647 * * *$ \\
\hline & $(0.01)$ & $(0.01)$ & $(0.01)$ & $(0.01)$ \\
\hline $\mathrm{N}$ & 1.244 & 1.541 & 1.244 & 1.541 \\
\hline Sargan & 0.9998 & 0.9999 & 0.8024 & 0.3236 \\
\hline $\mathrm{m} 1$ & 0.0000 & 0.0000 & 0.0000 & 0.0000 \\
\hline $\mathrm{m} 2$ & 0.1236 & 0.1244 & 0.1574 & 0.1500 \\
\hline
\end{tabular}

Again, our results are quite different from that of previous studies. In the study by López-Gracia and Sánchez-Andújar (2007), the only one that compared the speed of adjustment between family and non-family firms, family firms show faster speed of adjustment toward target leverage, whereas we find slower speed for Brazilian family firms. López-Gracia and Sánchez-Andújar (2007) argue that the lower level of family firms' debt can make it possible for these firms to use new debt to rapidly adjust their leverage. Since our sample of Brazilian family firms are over-leveraged, using new debt would make them to be even more leveraged. The adjustment, in this case, should be to decrease the leverage, perhaps with a new equity issuance. However, equity issuances are costly, making balancing of this nature less frequent and, thus, slowing the capital structure speed of adjustment.

The results remain qualitatively unchanged for the second criterion to define family firms. Columns III and IV show that these firms adjust leverage more slowly than non-family companies do. Employing the difference GMM estimator, the speed of adjustment is $73.32 \%(1-0.2281-0.0387)$ for family companies and $77.19 \%$ ( $1-0.2281)$ for non-family companies, while the system GMM estimator 
results are $40.63 \%(1-0.5579-0.0358)$ for family companies and $44.21 \%(1-0.5579)$ for non-family companies.

\section{Robustness check}

\section{Different definitions for family firms}

We test the robustness of our results by applying alternative definitions for family firms because the literature contains many variants. Table 7 shows the results of using three different definitions for family companies: (a) the LUS is a family and holds at least $10 \%$ of the voting rights (Maury, 2006), (b) the LUS is a family that holds at least $20 \%$ of voting rights (La Porta, Lopez-de-Silanes, \& Shleifer, 1999), and (c) a family or a person owns 33\% of the company's voting rights (Barth, Gulbrandsen, \& Schønea, 2005). As in Table 6, the coefficients in the odd columns were estimated with the Arellano and Bond's (1991) difference GMM estimator, and those in the even columns were estimated by applying the Blundell and Bond's (1998) system GMM estimator. The results remain qualitatively unaltered. All instruments are valid, the coefficients are significant, and there is no serial correlation. Confirming our previous analyses, the positive and significant coefficients of the interaction variable $\left(\mathrm{LEV}_{\mathrm{i}, \mathrm{t}-1} * \mathrm{FAM}_{\mathrm{i}, \mathrm{t}-1}\right)$ indicate that family companies are slower than non-family companies.

Table 7

Robustness Test of Speed of Adjustment

\begin{tabular}{|c|c|c|c|c|c|c|}
\hline & \multicolumn{2}{|c|}{ Voting rights: $10 \%$} & \multicolumn{2}{|c|}{ Voting rights: $20 \%$} & \multicolumn{2}{|c|}{ Voting rights: $33 \%$} \\
\hline & I (AB) & II (BB) & III (AB) & IV (BB) & V (AB) & VI (BB) \\
\hline \multirow[t]{2}{*}{ MktLevi,t-1 } & $0.2681 * * *$ & $0.5193 * * *$ & $0.2379 * * *$ & $0.5223 * * *$ & $0.2555^{* * *}$ & $0.5044 * * *$ \\
\hline & $(0.00)$ & $(0.00)$ & $(0.00)$ & $(0.00)$ & $(0.01)$ & $(0.00)$ \\
\hline \multirow[t]{2}{*}{ MktLevi,t-1*FAMi,t-1 } & $0.0590 * * *$ & $0.0952 * * *$ & $0.0675^{* * *}$ & $0.0948 * * *$ & $0.0610^{* * *}$ & $0.0886^{* * *}$ \\
\hline & $(0.00)$ & $(0.00)$ & $(0.00)$ & $(0,00)$ & $(0.00)$ & $(0.00)$ \\
\hline \multirow[t]{2}{*}{ EBIT_TAi,t-1 } & $-0.0833 * * *$ & $-0.2116 * * *$ & $-0.0814 * * *$ & $-0.2222 * * *$ & $-0.0844 * * *$ & $-0.1996 * * *$ \\
\hline & $(0.00)$ & $(0.01)$ & $(0.01)$ & $(0.01)$ & $(0.01)$ & $(0.01)$ \\
\hline \multirow[t]{2}{*}{ LnTAi,t-1 } & $0.0317 * * *$ & $0.0193 * * *$ & $0.0411 * * *$ & $0.0220 * * *$ & $0.0363 * * *$ & $0.0228 * * *$ \\
\hline & $(0.00)$ & $(0.00)$ & $(0.00)$ & $(0.00)$ & $(0.00)$ & $(0.00)$ \\
\hline \multirow[t]{2}{*}{ MTBi,t-1 } & $-0.0215^{* * *}$ & $-0.0343 * * *$ & $-0.0198 * * *$ & $-0.0349 * * *$ & $-0.0197 * * *$ & $-0.0328 * * *$ \\
\hline & $(0.00)$ & $(0.00)$ & $(0.00)$ & $(0.00)$ & $(0.00)$ & $(0.00)$ \\
\hline \multirow[t]{2}{*}{ DEP_TAi,t-1 } & $-0.1656 * * *$ & $-0.3893 * * *$ & $-0.0744 * * *$ & $-0.3707 * * *$ & -0.0729 & $-0.3785 * * *$ \\
\hline & $(0.06)$ & $(0.02)$ & $(0.03)$ & $(0.02)$ & $(0.03)$ & $(0.03)$ \\
\hline \multirow[t]{2}{*}{ FA_TAi,t-1 } & $0.0905^{* * *}$ & $0.1399 * * *$ & $0.0860 * * *$ & $0.1349 * * *$ & $0.0831 * * *$ & $0.1172 * * *$ \\
\hline & $(0.01)$ & $(0.01)$ & $(0.01)$ & $(0.01)$ & $(0.01)$ & $(0.01)$ \\
\hline \multirow[t]{2}{*}{ IND_LEVi,t-1 } & $-0.1442 * * *$ & $-0.1838 * * *$ & $-0.1193 * * *$ & $-0.1978 * * *$ & $-0.1328 * * *$ & $-0.1244 * * *$ \\
\hline & $(0.01)$ & $(0.01)$ & $(0.01)$ & $(0.01)$ & $(0.01)$ & $(0.01)$ \\
\hline
\end{tabular}

Continues 
Table 7 (continued)

\begin{tabular}{lllllll} 
& \multicolumn{2}{l}{ Voting rights: $10 \%$} & \multicolumn{2}{c}{ Voting rights: $20 \%$} & \multicolumn{2}{l}{ Voting rights: 33\% } \\
\cline { 2 - 7 } & I (AB) & II (BB) & III (AB) & IV (BB) & V (AB) & VI (BB) \\
\hline $\mathrm{N}$ & 1,244 & 1,541 & 1,244 & 1,541 & 1,244 & 1,541 \\
Sargan & 0.9999 & 0.3557 & 0.9981 & 0.4236 & 0.9974 & 1.00 \\
m1 & 0.0000 & 0.0000 & 0.0000 & 0.0000 & 0.0000 & 0.0000 \\
$\mathrm{~m} 2$ & 0.1215 & 0.1183 & 0.1205 & 0.1231 & 0.1271 & 0.1444 \\
\hline
\end{tabular}

Note. This table shows the results of estimating equation 5. Our sample is composed of all publicly traded companies in Bovespa (Brazil's stock exchange) in the 2003-2013 period, excluding firms from banking and public utilities industries. Variables are defined in Table 1 and the section on measures. We winsorize all variables at the upper and lower one-percentiles. We run regressions taking into account three different thresholds of LUS' voting rights to distinguish family firms from nonfamily firms: $10 \%, 20 \%$, and 33\%. Data are taken from Economatica, firms' financial statements, and CVM reports. The coefficients in columns (I), (III) and (V) were estimated by running the difference GMM estimator introduced by Arellano and Bond (1991), whereas the coefficients in columns (II), (IV) and (VI) were estimated by running the system GMM estimator introduced by Blundell and Bond (1998). Standard errors are in parentheses. Sargan refers to the Sargan test of overidentifying restrictions. $\mathrm{m} 1$ and $\mathrm{m} 2$ are the tests for first- and second-order autocorrelations.

$* * *, * *$ and $*$ represent statistical significance levels at one percent, five percent and ten percent.

\section{Ownership structure shifts}

An alternative explanation that could be driving our results is related to the fact that, over time, some successful family firms have become non-family firms due to mergers, acquisitions, or new equity issuances. As we can see from Table 8, several family firms became non-family, and vice versa, within the period under analysis. For example, according to our criterion 1 (LUS is a family regardless its shareholding), 46 family companies became non-family companies and 68 non-family companies became family companies. Thus, one may argue that our analyses are merely contrasting capital structure issues between the most successful family firms of the recent past — that are no longer family firms - to those firms that remained as family firms and that are, possibly, less successful.

Table 8

\section{Ownership Structure Shifts}

\begin{tabular}{ccccc}
\hline Year & \multicolumn{5}{l}{ Criterion 1 } & \multicolumn{2}{l}{ Criterion 2 } \\
\cline { 2 - 5 } & $\begin{array}{l}\text { From familiar to non- } \\
\text { familiar }\end{array}$ & $\begin{array}{l}\text { From non-familiar to } \\
\text { familiar }\end{array}$ & $\begin{array}{l}\text { From familiar to non- } \\
\text { familiar }\end{array}$ & $\begin{array}{l}\text { From non-familiar to } \\
\text { familiar }\end{array}$ \\
\hline 2004 & 6 & 6 & 6 & 4 \\
2005 & 6 & 1 & 7 & 2 \\
2006 & 3 & 5 & 6 & 6 \\
2007 & 4 & 6 & 4 & 4 \\
2008 & 10 & 7 & 8 & 7 \\
2009 & 4 & 6 & 2 & 7 \\
2010 & 7 & 29 & 15 & 11 \\
2011 & 2 & 4 & 5 & 3 \\
2012 & 1 & 3 & 3 & 2 \\
2013 & 3 & 1 & 3 & 5 \\
\hline TOTAL & 46 & 68 & 59 & 51 \\
\hline
\end{tabular}

Note. This table shows, year by year, the number of family firms that became non-family firms and vice versa. Criterion 1 distinguishes family firms from non-family firms by focusing on whether the LUS is a family regardless its shareholding, whereas criterion 2 , on whether the LUS is a family who controls the company. 
If the alternative explanation is true, neither the difference in leverage nor the difference in the speed of adjustment will be due to the family ownership, but to the firms' efficiency instead. To rule out this possible explanation, we re-run our analyses by assuming that family firms do not shift to nonfamily structure, and vice versa, within the period of analysis. That is, a given firm is set as familiar (non-familiar) throughout the whole period if it first appears in our sample as a family company (nonfamiliar). Our main results hold. Table 9 presents the summary statistics and indicates that family firms are still more leveraged, older, less profitable, less tangible and smaller than non-family firms.

Table 9

\section{Summary Statistics for Alternatives Criteria}

\begin{tabular}{|c|c|c|c|c|c|c|c|c|c|c|}
\hline \multirow[t]{3}{*}{ Variables } & \multicolumn{5}{|c|}{ Rigorous criterion 1} & \multicolumn{5}{|c|}{ Rigorous criterion 2} \\
\hline & \multicolumn{2}{|c|}{ Family firms } & \multicolumn{2}{|c|}{ Non-family firms } & \multirow[t]{2}{*}{ Diff } & \multicolumn{2}{|c|}{ Family firms } & \multicolumn{2}{|c|}{ Non-family firms } & \multirow[t]{2}{*}{ Diff } \\
\hline & $\mathrm{N}$ & Mean & $\mathrm{N}$ & Mean & & $\mathrm{N}$ & Mean & $\mathrm{N}$ & Mean & \\
\hline MktLev & 1208 & 0.319 & 907 & 0.273 & $0.045 * * *$ & 925 & 0.349 & 1190 & 0.261 & $0.087 * * *$ \\
\hline BookLev & 1208 & 0.245 & 907 & 0.249 & $-0.004 * *$ & 925 & 0.261 & 858 & 0.236 & $0.025 * * *$ \\
\hline EBIT_TA & 1209 & 0.068 & 907 & 0.091 & $-0.023 * * *$ & 926 & 0.066 & 858 & 0.087 & $-0.021 * * *$ \\
\hline LnTA & 1209 & 20.724 & 907 & 21.568 & $-0.844 * * *$ & 926 & 20.724 & 858 & 21.367 & $-0.642 * * *$ \\
\hline MTB & 1209 & 0.807 & 907 & 1.044 & $-0.236 * * *$ & 926 & 0.729 & 858 & 1.049 & $-0.320 * * *$ \\
\hline DEP_TA & 1149 & 0.030 & 907 & 0.043 & $-0.013 * * *$ & 874 & 0.031 & 842 & 0.040 & $-0.009 * * *$ \\
\hline FA_TA & 1209 & 0.281 & 907 & 0.295 & $-0.014 * * *$ & 926 & 0.298 & 858 & 0.279 & $0.019 * *$ \\
\hline AGE & 1206 & 42.771 & 879 & 35.949 & $6.822 * * *$ & 629 & 43.949 & 830 & 36.674 & $7.274 * * *$ \\
\hline
\end{tabular}

Note. This table presents the summary statistics of family and non-family firms according to the two robust criteria presented in this section. The sample is composed of all publicly traded companies in Bovespa (Brazil's stock exchange) in the $2003-$ 2013 period, excluding firms from banking and public utilities industries. Variables are defined in Table 1 and the section on measures. We winsorize all variables at the upper and lower one-percentiles. Rigorous criterion 1 distinguishes family firms from non-family firms by focusing on whether the LUS is a family regardless its shareholding in its first observation in our sample, whereas rigorous criterion 2 on whether the LUS is a family who controls the company when it first appears in our sample. Data are taken from Economatica, firms' financial statements, and CVM reports.

$* * *, * *$ and $*$ represent statistical significance levels at one percent, five percent, and ten percent.

Regarding the distance from target leverage, Table 10 shows that, regardless of the criterion, family firms are still significantly over-leveraged while non-family firms are under-leveraged.

Table 10

t-test of the Difference Between Means of the Firm's Target and Actual Market Leverage

$\begin{array}{ll}\text { Actual (1) Target (2) } & \begin{array}{l}\text { Difference } \\ (1)-(2)\end{array}\end{array}$

\begin{tabular}{llll}
\hline \multicolumn{3}{l}{ Panel A. Target leverage as fitted values of Model 1 } & \\
\hline Rigorous Criterion 1 & & & \\
Non-family firms & 0.281 & 0.304 & $-0.023^{* * *}$ \\
Family firms & 0.318 & 0.303 & $0.015^{* *}$ \\
\hline Rigorous Criterion 2 & & & \\
Non-family firms & 0.263 & 0.295 & $-0.033^{* * *}$ \\
Family firms & 0.351 & 0.313 & $0.038^{* * *}$ \\
\hline
\end{tabular}


Table 10 (continued)

\begin{tabular}{lll}
\hline Actual (1) & Target (2) & Difference \\
& & $(1)-(2)$
\end{tabular}

\begin{tabular}{|c|c|c|c|}
\hline \multicolumn{4}{|c|}{ Panel B. Target leverage as fitted values of Model 2} \\
\hline \multicolumn{4}{|c|}{ Rigorous Criterion 1} \\
\hline Non-family firms & 0.281 & 0.318 & $-0.037 * * *$ \\
\hline Family firms & 0.318 & 0.294 & $0.024 * *$ \\
\hline \multicolumn{4}{|c|}{ Rigorous Criterion 2} \\
\hline Non-family firms & 0.263 & 0.318 & $-0.055^{* * *}$ \\
\hline Family firms & 0.351 & 0.287 & $0.064 * * *$ \\
\hline
\end{tabular}

Note. This table presents the t-test of the difference between means of the company's target and actual market leverage. The sample is composed of all publicly traded companies in Bovespa (Brazil's stock exchange) in the 2003-2013 period, excluding firms from banking and public utilities industries. We winsorize all variables at the upper and lower one-percentiles. Rigorous criterion 1 distinguishes family firms from non-family firms by focusing on whether the LUS is a family regardless its shareholding in its first observation in our sample, whereas rigorous criterion 2 on whether the LUS is a family who controls the company when it first appears in our sample. Data are taken from Economatica, firms' financial statements, and CVM reports.

$* * *, * *$ and $*$ represent statistical significance levels at one percent, five percent, and ten percent.

Table 11 presents the estimation of the speed of adjustment. As in the prior subsections, the odd and even columns refer to the first-differences GMM and system GMM, respectively. As we can see, even using more rigorous criteria to define whether a firm is familiar or not, the results are supportive of our main ones.

Table 11

Speed of Adjustment to the Target Leverage Using Rigorous Family Criteria

\begin{tabular}{|c|c|c|c|c|}
\hline & \multicolumn{2}{|c|}{ Rigorous criterion 1} & \multicolumn{2}{|c|}{ Rigorous criterion 2} \\
\hline & $\mathrm{I}(\mathrm{AB})$ & II (BB) & III (AB) & IV (BB) \\
\hline \multirow[t]{2}{*}{ MktLevi,t-1 } & $0.2390 * * *$ & $0.5110 * * *$ & $0.2713 * * *$ & $0.5221 * * *$ \\
\hline & $(0.00)$ & $(0.00)$ & $(0.00)$ & $(0.00)$ \\
\hline \multirow[t]{2}{*}{ MktLevi,t-1*FAMi,t-1 } & $0.0546 * * *$ & $0.0644 * * *$ & 0.0058 & $0.0743^{* * *}$ \\
\hline & $(0.01)$ & $(0.00)$ & $(0.01)$ & $(0.00)$ \\
\hline \multirow[t]{2}{*}{ EBIT_TAi,t-1 } & $-0.0669 * * *$ & $-0.2240 * * *$ & $-0.0773 * * *$ & $-0.2105 * * *$ \\
\hline & $(0.01)$ & $(0.00)$ & $(0.00)$ & $(0.01)$ \\
\hline \multirow[t]{2}{*}{ LnTAi,t-1 } & $0.0366^{* * *}$ & $0.0181 * * *$ & $0.0431 * * *$ & $0.0148^{* * *}$ \\
\hline & $(0.00)$ & $(0.00)$ & $(0.00)$ & $(0.00)$ \\
\hline \multirow[t]{2}{*}{ MTBi,t-1 } & $-0.0207 * * *$ & $-0.0355 * * *$ & $-0.0165 * * *$ & $-0.0354 * * *$ \\
\hline & $(0.00)$ & $(0.00)$ & $(0.00)$ & $(0.00)$ \\
\hline \multirow[t]{2}{*}{ DEP_TAi,t-1 } & -0.0649 & $-0.3598 * * *$ & $0.0808 * *$ & $-0.3032 * * *$ \\
\hline & $(0.06)$ & $(0.04)$ & $(0.04)$ & $(0.04)$ \\
\hline \multirow[t]{2}{*}{ FA_TAi,t-1 } & $0.0960 * * *$ & $0.1287 * * *$ & $0.0866^{* * *}$ & $0.1199 * * *$ \\
\hline & $(0.00)$ & $(0.00)$ & $(0.01)$ & $(0.00)$ \\
\hline \multirow[t]{2}{*}{ IND_LEVi,t-1 } & $-0.1183 * * *$ & $-0.1501 * * *$ & $-0.1095 * * *$ & $-0.1540 * * *$ \\
\hline & $(0.01)$ & $(0.01)$ & $(0.01)$ & $(0.01)$ \\
\hline $\mathrm{N}$ & 1.244 & 1.541 & 1.2414 & 1.541 \\
\hline Sargan & 0.9998 & 0.9999 & 0.8024 & 0.3236 \\
\hline $\mathrm{m} 1$ & 0.0000 & 0.0000 & 0.0000 & 0.0000 \\
\hline $\mathrm{m} 2$ & 0.1154 & 0.1352 & 0.1153 & 0.1328 \\
\hline
\end{tabular}




\section{Discussion and Conclusions}

Most studies show family firms being less leveraged and faster in adjusting their capital structure than non-family firms. Our findings are strikingly different from these previous studies conducted in other countries and indicate that Brazilian family companies have higher leverage and a slower speed of adjustment. These two findings constitute our main contribution. We argue that managers' overconfidence and optimism that make family firms be more leveraged, and consequently more financially constrained, are the major reasons for their slower adjustment to the target leverage. Optimistic managers have the tendency to overestimate the future cash flow their firms, while overconfident managers underestimate the firm's risk, thereby leading to overestimation of the firm's future performance and present value.

Thus, overconfident and optimistic managers have the tendency to depend more intensively on debt because they believe their firms will be able to pay the liability. Moreover, these managers believe that external financing, particularly new equity, is overpriced (i.e., excessively costly). If trade-off theory holds, over-leveraged family firms will rebalance their capital structure by either retiring debt (less likely) or issuing new equity. However, since issuing new equity involves high direct (i.e., gross spreads) and indirect (i.e., underpricing) costs, rebalancing capital structure using this mechanism is not frequent, thereby slowing capital structure adjustments.

Although we attribute family companies' slower adjustment to their higher probability of being financially constrained (i.e., over-leverage excludes or limits the possibility of raising more debt as an external financing alternative), we can speculate about other possible motives for family companies to be over-leveraged, irrespective of the financial constraints rationale. For example, given the controlling families' goal of commanding the company over multiple generations, they can prefer to use internal resources first (i.e., cash flow from ongoing operations) to finance their investment needs (BlancoMazagatos et al., 2007) and avoid issuing new equity to not lose control over their firms. In doing so, family firms intentionally choose to keep themselves smaller than their non-family counterparts. That is, they self-select to be small. If this is true, family firms will seem more financially constrained in terms of size than non-family firms, which would not necessarily be the case. Anyway, this alternative explanation does not rule out the fact that family firms are more financially constrained due to their over-leverage status.

Another possible explanation, also not explored in our article, is related to the peculiar Brazilian credit market. Since Brazilian firms have access to subsidized loans from BNDES (the state-owned development bank), it is not clear whether this external finance channel can create opportunities for firms to deviate from their targets. However, this is an issue to be addressed by future studies.

\section{References}

Abadie, A., Drukker, D., Herr, J. L., \& Imbens, G. W. (2004). Implementing matching estimators for average treatment effects in Stata. The Stata Journal, 4(3), 290-311.

Abadie, A., \& Imbens, G. W. (2011). Bias-corrected matching estimators for average treatment effects. Journal of Business \& Economic Statistics, 29(1), 1-11. http://dx.doi.org/10.1198/jbes.2009.07333

Agrawal, A., \& Nagarajan, N. J. (1990). Corporate capital structure, agency costs, and ownership control: The case of all-equity firms. The Journal of Finance, 45(4), 1325-1331. http://dx.doi.org/10.1111/j.1540-6261.1990.tb02441.x 
Anderson, R. C., \& Reeb, D. M. (2003a). Founding-family ownership and firm performance: Evidence from the S\&P 500. The Journal of Finance, 58(3), 1301-1327. http://dx.doi.org/10.1111/15406261.00567

Anderson, R. C., \& Reeb, D. M. (2003b). Founding-family ownership, corporate diversification, and firm leverage. The Journal of Law \& Economics, 46(2), 653-684. http://dx.doi.org/10.1086/377115

Anderson, R. C., Mansi, S. A., \& Reeb, D. M. (2003). Founding family ownership and the agency cost of debt. Journal of Financial Economics, 68(2), 263-285. http://dx.doi.org/10.1016/S0304405X(03)00067-9

Arellano, M., \& Bond, S. (1991). Some tests of specification for panel data: Monte Carlo evidence and an application to employment equations. The Review of Economic Studies, 58(2), 277-297. http://dx.doi.org/10.2307/2297968

Baker, M., \& Wurgler, J. (2002). Market timing and capital structure. The Journal of Finance, 57(1), 132. http://dx.doi.org/10.1111/1540-6261.00414

Baltagi, B. H. (2008). Econometric analysis of panel data (4th ed.). Chichester, UK; Hoboken, NJ: John Wiley \& Sons.

Barros, L. A. B. C., \& Silveira, A. D. M. (2008). Excesso de confiança, otimismo gerencial e os determinantes da estrutura de capital. Revista Brasileira de Finanças, 6(3), 293-334.

Barth, E., Gulbrandsen, T., \& Schønea, P. (2005). Family ownership and productivity: The role of owner-management. Journal of Corporate Finance, 11(1/2), 107-127. http://dx.doi.org/10.1016/j.jcorpfin.2004.02.001

Blanco-Mazagatos, V., Quevedo-Puente, E. de, \& Castrillo, L. A. (2007). The trade-off between financial resources and agency costs in the family business: An exploratory study. Family Business Review, 20(3), 199-213. http://dx.doi.org/10.1111/j.1741-6248.2007.00095.x

Blundell, R., \& Bond, S. (1998). Initial conditions and moment restrictions in dynamic panel data models. Journal of Econometrics, $87(1), \quad 115-143 . \quad$ http://dx.doi.org/10.1016/S03044076(98)00009-8

Bogéa, L. R., Sobrinho, Sheng, H. H., \& Lora, M. I. (2012). Country factors and dynamic capital structure in Latin American firms. Revista Brasileira de Finanças, 10(2), 267-284.

Butler, A. W., Grullon, G., \& Weston, J. P. (2005). Stock market liquidity and the cost of issuing equity. Journal of Financial and Quantitative Analysis, 40(2), 331-348. http://dx.doi.org/10.1017/S0022109000002337

Chang, Y.-K., Chen, Y.-L., Chou, R. K., \& Huang, T.-H. (2015). Corporate governance, product market competition and dynamic capital structure. International Review of Economics \& Finance, 38, 44-55. http://dx.doi.org/10.1016/j.iref.2014.12.013

Chang, Y.-K., Chou, R. K., \& Huang, T.-H. (2014). Corporate governance and the dynamics of capital structure: New evidence. Journal of Banking \& Finance, 48, 374-385. http://dx.doi.org/10.1016/j.jbankfin.2014.04.026

Corwin, S. A. (2003). The determinants of underpricing for seasoned equity offers. The Journal of Finance, 58(5), 2249-2279. http://dx.doi.org/10.1111/1540-6261.00604

Crespí, R., \& Martín-Oliver, A. (2015). Do family firms have better access to external finance during crises? Corporate Governance: An International Review, 23(3), 249-265. http://dx.doi.org/10.1111/corg.12100 
DeAngelo, H., \& Roll, R. (2015). How stable are corporate capital structures? The Journal of Finance, 70(1), 373-418. http://dx.doi.org/10.1111/jofi.12163

Dudley, E. (2012). Capital structure and large investment projects. Journal of Corporate Finance, 18(5), 1168-1192. http://dx.doi.org/10.1016/j.jcorpfin.2012.07.007

Elsas, R., \& Florysiak, D. (2011). Heterogeneity in the speed of adjustment toward target leverage. International Review of Finance, 11(2), 181-211. http://dx.doi.org/10.1111/j.14682443.2011.01130.x

Fahlenbrach, R. (2009). Founder-CEOs, investment decisions, and stock market performance. Journal of Financial and Quantitative Analysis, 44(2), 439-466. http://dx.doi.org/10.1017/S0022109009090139

Fama, E. F., \& French, K. R. (1992). The cross-section of expected stock returns. The Journal of Finance, 47(2), 427-427. http://dx.doi.org/10.1111/j.1540-6261.1992.tb04398.x

Fama, E. F., \& French, K. R. (2002). Testing trade-off and pecking order predictions about dividends and debt. The Review of Financial Studies, 15(1), 1-33. http://dx.doi.org/10.1093/rfs/15.1.1

Faulkender, M., Flannery, M. J., Hankins, K. W., \& Smith, J. M. (2012). Cash flows and leverage adjustments. Journal of Financial Economics, 103(3), 632-646. http://dx.doi.org/10.1016/j.jfineco.2011.10.013

Flannery, M. J., \& Hankins, K. W. (2013). Estimating dynamic panel models in corporate finance. Journal of Corporate Finance, 19, 1-19. http://dx.doi.org/10.1016/j.jcorpfin.2012.09.004

Flannery, M. J., \& Rangan, K. P. (2006). Partial adjustment toward target capital structures. Journal of Financial Economics, 79(3), 469-506. http://dx.doi.org/10.1016/j.jfineco.2005.03.004

Gallo, M. Á., Tàpies, J., \& Cappuyns, K. (2004). Comparison of family and nonfamily business: Financial logic and personal preferences. Family Business Review, 17(4), 303-318. http://dx.doi.org/10.1111/j.1741-6248.2004.00020.x

Graham, J. R., \& Harvey, C. R. (2001). The theory and practice of corporate finance: Evidence from the field. Journal of Financial Economics, 60(2/3), 187-243. http://dx.doi.org/10.1016/S0304405X(01)00044-7

Hackbarth, D. (2008). Managerial traits and capital structure decisions. Journal of Financial and Quantitative Analysis, 43(4), 843. http://dx.doi.org/10.1017/S002210900001437X

Heaton, J. B. (2002). Managerial optimism and corporate finance. Financial Management, 31(2), 3345. http://dx.doi.org/10.2139/ssrn.71411

Hovakimian, A., Opler, T., \& Titman, S. (2001). The debt-equity choice. Journal of Financial and Quantitative Analysis, 36(1), 1-24. http://dx.doi.org/10.2307/2676195

Huang, R., \& Ritter, J. R. (2009). Testing theories of capital structure and estimating the speed of adjustment. Journal of Financial and Quantitative Analysis, 44(2), 237-271. http://dx.doi.org/10.1017/S0022109009090152

Jensen, M. C. (1986). Agency costs of free cash flow, corporate finance, and takeovers. The American Economic Review, 76(2), 323-329.

Korajczyk, R. A., \& Levy, A. (2003). Capital structure choice: Macroeconomic conditions and financial constraints. Journal of Financial Economics, 68(1), 75-109. http://dx.doi.org/10.1016/S0304405X(02)00249-0 
Kraus, A., \& Litzenberger, R. H. (1973). A state-preference model of optimal financial leverage. The Journal of Finance, 28(4), 911-922. http://dx.doi.org/10.1111/j.1540-6261.1973.tb01415.x

Kuo, Y.-P., \& Hung, J.-H. (2012). Family control and investment-cash flow sensitivity: Moderating effects of excess control rights and board independence. Corporate Governance: An International Review, 20(3), 253-266. http://dx.doi.org/10.1111/j.1467-8683.2011.00899.x

La Porta, R., Lopez-de-Silanes, F., \& Shleifer, A. (1999). Corporate ownership around the world. The Journal of Finance, 54(2), 471-517. http://dx.doi.org/10.1111/0022-1082.00115

Lee, G., \& Masulis, R. W. (2009). Seasoned equity offerings: Quality of accounting information and expected flotation costs. Journal of Financial Economics, 92(3), 443-469. https://doi.org/10.1016/j.jfineco.2008.04.010

Lemmon, M. L., Roberts, M. R., \& Zender, J. F. (2008). Back to the beginning: Persistence and the cross-section of corporate capital structure. The Journal of Finance, 63(4), 1575-1608. http://dx.doi.org/10.1111/j.1540-6261.2008.01369.x

López-Gracia, J., \& Sánchez-Andújar, S. (2007). Financial structure of the family business: Evidence from a group of small Spanish firms. Family Business Review, 20(4), 269-287. http://dx.doi.org/10.1111/j.1741-6248.2007.00094.x

Lyandres, E. (2010). Target leverage and the costs of issuing seasoned equity. Finance Research Letters, 7(1), 39-52. http://dx.doi.org/10.1016/j.frl.2009.11.004

Malmendier, U., Tate, G., \& Yan, J. O. N. (2011). Overconfidence and early-life experiences: The effect of managerial traits on corporate financial policies. The Journal of Finance, 66(5), 1687-1733. http://dx.doi.org/10.1111/j.1540-6261.2011.01685.x

Maury, B. (2006). Family ownership and firm performance: Empirical evidence from Western European

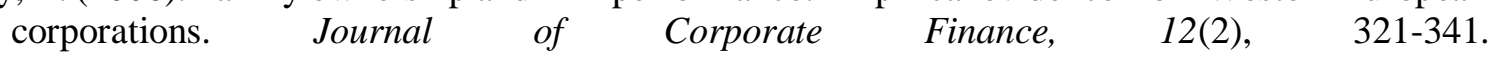
http://dx.doi.org/10.1016/j.jcorpfin.2005.02.002

McConaughy, D. L., Matthews, C. H., \& Fialko, A. S. (2001). Founding family controlled firms: performance, risk, and value. Journal of Small Business Management, 39(1), 31-49. http://dx.doi.org/10.1111/0447-2778.00004

Miller, D., Le Breton-Miller, I., Lester, R. H., \& Cannella, A. A., Jr. (2007). Are family firms really superior performers? Journal of Corporate Finance, 13(5), 829-858. http://dx.doi.org/10.1016/j.jcorpfin.2007.03.004

Miralles-Marcelo, J. L., Miralles-Quirós, M. D. M., \& Lisboa, I. (2014). The impact of family control on firm performance: Evidence from Portugal and Spain. Journal of Family Business Strategy, 5(2), 156-168. http://dx.doi.org/10.1016/j.jfbs.2014.03.002

Modigliani, F., \& Miller, M. H. (1958). The cost of capital, corporation finance and the theory of investment. American Economic Review, 48(3), 261-297.

Myers, S. C. (1977). Determinants of corporate borrowing. Journal of Financial Economics, 5(2), $147-$ 175. http://dx.doi.org/10.1016/0304-405X(77)90015-0

Myers, S. C., \& Majluf, N. S. (1984). Corporate financing and investment decisions when firms have information that investors do not have. Journal of Financial Economics, 13(2), 187-221. http://dx.doi.org/10.1016/0304-405X(84)90023-0

Schmid, T., Ampenberger, M., Kaserer, C., \& Achleitner, A.-K. (2015). Family firm heterogeneity and corporate policy: evidence from diversification decisions. Corporate Governance: An International Review, 23(3), 285-302. http://dx.doi.org/10.1111/corg.12091 
Uysal, V. B. (2011). Deviation from the target capital structure and acquisition choices. Journal of Financial Economics, 102(3), 602-620. http://dx.doi.org/10.1016/j.jfineco.2010.11.007

Wagner, D., Block, J. H., Miller, D., Schwens, C., \& Xi, G. (2015). A meta-analysis of the financial performance of family firms: Another attempt. Journal of Family Business Strategy, 6(1), 3-13. http://dx.doi.org/10.1016/j.jfbs.2015.01.001

Welch, I. (2004). Capital structure and stock returns. The Journal of Political Economy, 112(1), 106131. http://dx.doi.org/10.1086/379933

\section{Authors' Profiles}

Eduardo K. Kayo

Av. Prof. Luciano Gualberto, 908, 05508-010, São Paulo, SP, Brazil. E-mail address: kayo@usp.br

Eduardo Ottoboni Brunaldi

Av. Prof. Luciano Gualberto, 908, 05508-010, São Paulo, SP, Brazil. E-mail address: eduardo.brunaldi@usp.br

Dante M. Aldrighi

Av. Prof. Luciano Gualberto, 908, 05508-010, São Paulo, SP, Brazil. E-mail address: aldrighi@ usp.br 